\title{
A POTENCY AND CHALLENGE OF WAREHOUSE RECEIPTS SYSTEM (WRS) IMPLEMENTATION IN NIAGA MUKTI COOPERATION, CIANJUR
}

\author{
Potensi dan Tantangan Sistem Resi Gudang (WRS) Implementasi \\ pada Koperasi Niaga Mukti, Cianjur
}

\author{
Ukhwatul Khasanah ${ }^{1}$, Dwidjono Hadi ${ }^{2}$, Slamet Hartono ${ }^{2}$, Liana Fatma Leslie Pratiwi ${ }^{1}$ \\ ${ }^{1}$ Student in Master of Agribussiness Management, Gadjah Mada University,Yogyakarta \\ ${ }^{2}$ Lecture in Master of Agribussiness Management, Gadjah Mada University, Yogyakarta \\ Jl. Flora, Bulaksumur, Kec.Depok, Kabupaten Sleman, \\ Daerah Istimewa Yogyakarta 55281 \\ kh_sanah@yahoo.com
}

Diterima tanggal 1 Juni 2017 ; Disetujui tanggal 15 Mei 2017

\begin{abstract}
Declining of agricultural commodity prices during the harvest season has become detrimental to farmers. It often makes farmers not harvest their crops because the cost of harvesting is more expensive than the selling price of the product. The government makes a Warehouse Receipt System (WRS) program to help farmer to solve the cost of farm business and anticipation of low price of farmer income in harvest time. The goal of the research is to analyze and to describe regarding the potency and challenge of warehouse receipts system implementation in Niaga Mukti Cooperation, Cianjur. The method used was descriptive analysis with the subject of Niaga Mukti Cooperation as the sample of WRS for rice commodity. The result of the research shows that warehouse receipts system has potency to become collateral credit document to obtain farming budgeting for the member of Niaga Mukti cooperation with $6 \%$ per year or $1,5 \%$ per month after receiving government grant. In conducting WRS program, the cooperation confronts various challenges such as economic society empowerment through WRS, warehouse empowerment receipts as alternative finance, finance instruments and agricultural marketing. However, it requires coordination and correlation among the government, regions, farm cooperation, endeavor and finance institutions.
\end{abstract}

Keywords: challengers, Niaga Mukti cooperation, potential, warehouse receipt system

\section{INTISARI}

Penurunan harga komoditas pertanian selama musim panen telah merugikan petani. Seringkali membuat petani tidak memanen hasil panen usahaninya karena biaya panen lebih mahal dari harga jual produk tani. Pemerintah membuat program Warehouse Receipt System (WRS) untuk membantu petani dalam menyelesaikan masalah biaya usahatani dan mengantisipasi rendahnya pendapatan petani pada saat panen. Tujuan dari penelitian ini adalah untuk menganalisis dan mendeskripsikan mengenai potensi dan tantangan implementasi sistem resi gudang pada Koperasi Niaga Mukti, Cianjur. Metode yang digunakan adalah analisis deskriptif dengan subjek Niaga Mukti Cooperation sebagai sampel sistem resi gudang (WRS) untuk komoditas padi. Hasil penelitian menunjukkan bahwa sistem resi gudang berpotensi sebagai dokumen kredit jaminan untuk mendapatkan pembiayaan peternakan bagi anggota koperasi Niaga Mukti dengan bunga 6\% per tahun atau 1,5\% per 
bulan setelah mendapat hibah dari pemerintah. Dalam melaksanakan program sistem resi gudang (WRS), kerjasama tersebut menghadapi berbagai tantangan seperti pemberdayaan masyarakat ekonomi melalui sistem resi gudang (WRS), pemberdayaan penerimaan gudang sebagai alternatif pembiayaan, instrumen keuangan dan pemasaran untuk pertanian dan memerlukan koordinasi dan korelasi antara pemerintah, daerah, kerjasama pertanian, usaha, dan Lembaga keuangan.

Kata kunci : competitor, koperasi Niaga Mukti, potensi, sistem resi gudang

\section{INTRODUCTION}

Agriculture sector is one of the components of national construction toward food supremacy to remove poverty. After five years (2010-2014) agriculture sector gives a big contribution after industrial sector and cultivation. The superior commodity of agricultural sector is food plant. On the other hand, Bappenas, Indonesia as agriculture country is the tenth biggest producer agriculture in the world. Based on agriculture census in 2013, agriculture sector still absorbs the biggest employee with the percentage of $34,6 \%$ from total number of employee, while the contribution to gross domestic product is $15 \%$. In the mean time, agriculture product import in 2003-2013 is big from US\$ 3,34 billion up to US\$ 14,90 billion.

The important roles of agriculture sector in national cultivation are to absorb the employee, to contribute Gross Domestic Product (GDP), to increase country currency exchange to be used as the source of industry basic commodity, food and nutrition and to be used as the promoter of other economic sector.
The condition is caused by some problems of agriculture sector. According to Apriyantono (2004), some of agriculture problems in Indonesia are modal and price. Farmer (modal side) is confronted by the less of endeavor capital and price, less of mind of banking system to the farmer, unavailability of agriculture assurance, and ijon system. On the other hand, farmer (price side) obtains inappropriate cost, fluctuating, based on trader, and lost. Farmer is confronted by the decreasing cost in harvest time while the need of farm must be fulfilled.

Farmers are still dealing with classic problem that is seeking finance for farming and declining output price during the harvest season. Access to capital assistance from banks is still very difficult because farmers often have difficulty to find collateral as a requirement for loans (Elias, 2016).

Contribution of agriculture sector toward GDB can be seen in Table 1.

In addition, declining of agricultural commodity prices, especially during the harvest season, has become a definite problem that is detrimental to farmers. In 
Table 1. GDB Structure According to Business Enterprise Area Based on Valid Price of Percent

\begin{tabular}{lrrrrr}
\hline Business enterprise & \multicolumn{1}{c}{2010} & \multicolumn{1}{c}{2011} & \multicolumn{1}{c}{2012} & \multicolumn{1}{c}{2013} & \multicolumn{1}{c}{2014} \\
\hline Agriculture, Livestock, Forestry and Fishery & 15,29 & 14,70 & 14,44 & 14,43 & 14,33 \\
Mining and Excavation & 11,16 & 11,85 & 11,78 & 11,24 & 10,48 \\
Cultivation industry & 24,80 & 24,33 & 23,04 & 23,69 & 23,71 \\
Electricity, Gas, and Hygienic Water & 0,76 & 0,77 & 0,79 & 0,77 & 0,80 \\
Construction & 10,25 & 10,16 & 20,45 & 9,99 & 10,05 \\
Trading, Hotel and Restaurant & 13,69 & 13,80 & 13,90 & 14,33 & 14,24 \\
Transportation and Communication & 6,57 & 6,62 & 6,66 & 7,01 & 7,39 \\
Finance, Real Estate and Company expense & 7,24 & 7,21 & 7,26 & 7,52 & 7,64 \\
Expense & 10,24 & 10,56 & 10,78 & 11,02 & 10,98 \\
GDP & 100 & 100 & 100 & 100 & 100 \\
\hline
\end{tabular}

Source: Statistic Center Committee (2014)

fact, it often makes farmers not harvest their crops because the cost of harvesting is more expensive than the selling price of the product (Muhi, 2011 cit. Listiani and Bagas, 2013). Actually, farmers can make a strategy by delaying to sale a product to avoid losses due to low prices during the harvest season. However, farmers do not have strong bargaining position not to sell their products. The condition occurs since most farmers consider that their harvest product as "cash crop". It means, farmers need cash money in that time to fulfill their household needs and also to prepare their farming in the next planting season (Ashari, 2011 cit. Listiani and Bagas, 2013).

According to Nugrayasa (2012), there are five basic reasons of agriculture in Indonesia. The first is decreasing quality and resource quantity of agriculture field. The second is limited availability of infrastructure agriculture support that is construction and reservoir development. The third is the weakness of technology exchange system including technology after harvest. The fourth is the ability of farmer to afford their limited farm business so that the productivity is far from potential productivity. The fifth is the continuity of agriculture business administration that causes farmers become unable to enjoy the better price because trader has taken the biggest profit from trading product.

Income level of farmer is generally influenced by total production, cost, and farm business cost. The income of farmer is generally low, yet they conduct of endeavor in agriculture such as rice. One of the basic reasons is rice which is the primary food of Indonesia. Therefore, rice farm business is one of the commodities which have a prospect to increase the income of farmer. According to Suryadi et al. (2008), the main challenge of the rice productivity and productivity improvement program is how to make rice farming more efficient, so that it has competitiveness and is viable as a sustainable source of income. The rice 
production improvement program still faces a number of obstacles, including low rice prices at farmers level, very low grain / rice exchange rates, ineffective implementation of rice import tariffs to protect domestic rice prices, food procurement credits using commercial interest rates and Food Security Loans (KKP) that has not been channeled smoothly, limited ability of farmers to store grain to get the desired selling price, and dependence on rice as a source of carbohydrate is still high enough that is $120-130 \mathrm{~kg} /$ capita / year.

However, rice farm business is one of the commodities which has a prospect to increase the income of farmer. It motivates them to increase their production with the high income in harvest time to fulfill their daily need. Farmer often confronts the fall of commodity price in harvest time. However, they need money to their modal of farm business or the debt before fulfilling their need.

Predicted agricultural commodity prices become one of the important marketing factors for farmers, especially in the process of warehousing (storage). This is because price plays an important role in the optimization of market formation and marketing strategy. On the other hand, price formation is important for the government in taking policy. Government policies are established and implemented based on the prediction of economic variables in the short and long term, including the variables of agricultural commodity prices (Pargami et al., 2013).

The government through trading minister makes a program to help farmer to solve the cost of farm business and anticipation of low price of farmer income in harvest time. The program is Warehouse Receipt System (WRS). Warehouse receipt system is the activity of publishing, changing, guaranteeing and finishing of transaction of WRS which is then changed into the law No. 9 in 2011. In its implementation, WRS is organized through the regulation of government No. 36 in 2007 regarding the implementation of Regulation No. 92006. Warehouse receipt is the document of the ownership evidence toward commodity that is saved in warehouse receipt system. Warehouse receipt is published by manager of warehouse used to obtain scheme of warehouse receipt grant. It is a credit for the holder of warehouse receipt that obtains the grant from government with guarantee of commodity saved. Credit of S-WRG is able to be offered to finance institution of non bank with an agreement.

Tosun, Savran et al. (2014) in a study entitled "The evaluation of the warehouse receipt system for agro-food products in Turkey states" suggests that the agribusiness structure in Turkey is small, especially in terms of production. This causes the farmers sell the crops directly for the next farming purposes. With the 
Warehouse Receipts System provides benefits for Turkey farmers in terms of obtaining credit from banks and improve efficiency in time and cost.

Onumah (2010) in his research entitled "Implementing Warehouse Receipt System in Africa Potential and Challenges states that the implementation of Warehouse Receipts System in Africa was successful, especially in Tanzania" stated that Warehouse Receipts System can reduce transaction costs and strengthen local and regional market capacities. Warehouse Receipts System activities can also absorb surpluses so as to increase output and avoid loss of price margins that are producer incentives. Some of the challenges faced can be solved by the cooperation between the government and the private sector. The biggest challenge is policy uncertainty. Warehouse receipt financing is often unsuitable for rural producers, especially small farmers in Africa, warehouse receipts are used primarily by some large borrowers usually importers under collateral management arrangements involving international inspection firms.

The implementation of scheme warehouse receipt grant is founded by the regulation of trading minister No 66/M-DAG/PER/12/2009. Based on the regulation, the activity of productive of agriculture sector is able to be paid through S-WRG by using warehouse receipt as the guarantee. Through the credit loan with WRG scheme, farmer is only burdened for 6 percent per year from total of the debt because the government gives a grant with the quarrel between valid interest income and the burden interest income that must be paid farmer as the debtor. Concept of WRG is expected to give motivation of endeavor development for the farmer.

Another objective of the SRG program is to help farmers irrespective of the problem of low commodity prices during the harvest season with delay mechanisms. The postponement mechanism provides an opportunity for farmers to store their crops to Warehouse Receipts System warehouse for a certain period of time until an estimated price increase occurs. This mechanism can also help control fluctuations in prices due to seasonal commodities. The phenomenon of price fluctuations caused by unscrupulous in this case the owner of the warehouse deliberately stock up commodities in the warehouse with the aim to boost prices in the market, consequently there is a massive sale especially when prices rise in the famine season. This action will push the price down to a lower level. Therefore, Warehouse Receipts System serves as a provider of price information, buyers and updated pricing information and examines factors that will affect future price fluctuations. Onumah (2010) revealed that as a long-term goal, Warehouse Receipts 
System can contribute to increasing the income of rural farming by promoting trade in agricultural commodities and increasing access to loans for farmers.

Implementation of Warehouse Receipt Program in Indonesia start since 2008 with four pilot districts namely Kabupaten Banyumas, Jombang, Indramayu and Gowa. The next few years, Cianjur regency chosen to be a pilot area of Warehouse Receipts System implementation for grain and rice commodities with Niaga Mukti Cooperative as warehouse manager under the supervision of Bappebti. Then, Warehouse Receipts System developing in 2009 until 2014 with increasing number of Warehouses and the number of farmers, farmer groups and cooperatives that utilize Warehouse Receipts System (WRS).

West Java Province is the second highest rank of rice producers in 2014. One of the fastest WRS sites developing is in Kabupaten Cianjur. In 2011 to 2015 the number of warehouse receipts in Cianjur Regency is 98 warehouse receipts under the management of PT. Pertani and 139 warehouse receipts managed by Niaga Mukti Cooperative. From the number of warehouse receipts issued, as much as $98 \%$ used by farmers collaterally in the bank BJB to obtain credit farming. However, the number of grain commodities that participated in the WRS program has not been maximum compared to the potential of these commodities. It is very interesting to investigate, although Cianjur District is very potential to be developed but the interest of some people to utilize WRS is still low.

The introduction of warehouse receipt (WR) was expected to reduce these problems within smallholder farmers. (Anitasari, 2015). However, WRS is still unavailable to the major of smallholder farmers who face cumbersome lending procedures (Towo, 2014).

The goal of the research is to analyze and describe the potency and challenge implementation of warehouse receipts system in Niaga Mukti Cooperation, Cianjur.

\section{Warehouse Receipts: Facilitating Finance and Commodity Markets}

The warehouse receipts system, also known as inventory credits, can facilitate financing for inventory or products held in storage. These receipts, sometimes known as warrants, when backed by legal provisions that guarantee quality, provide a secure system whereby stored agricultural commodities can serve as collateral, be sold, traded or used for delivery against financial instruments including futures contracts. These receipts are documents that state the ownership of a specific quantity of products with specific characteristics and stored in a specific warehouse (Hasnain, et.al., 2014). 
Warehouse receipt finance can be provided under different warehousing arrangements (Hasnain, et.al., 2014):

- In a private warehouse, manufacturing and warehousing take place under the same roof, and both activities are controlled by the same company. The warehouse is just a part of the overall company operations, which may be manufacturing, wholesaling or retailing. It is very risky to use commodities in private warehouses as collateral for loans: other than spot checks by the bank, there is little to ensure that the goods are really present.

- A field warehouse is an arrangement where a collateral management or credit support company takes over the warehouse of a depositor (producer/ customer) or a public warehouse by leasing it (or part of it) for a nominal fee, and becomes responsible for the control of the commodities to be used as collateral

- A public warehouse is normally a large storage area that serves many businesses, for example in a port or major transit centre. It is owned (or rented for a long period) and operated by a warehouse operator, which stores commodities for third parties for a fee and acts as the commodities' custodian.

Public warehouse operators often issue warehouse receipts that are acceptable as collateral by banks. However, the quality of the receipt as collateral depends on many factors, particularly the legal and regulatory regime in the country, and the financial status and integrity of the warehouse operator.

\section{The Roles of Diverse Actors (Hasnain, et.al., 2014) :}

A successful warehouse receipts scheme relies on clear division of responsibility and clear co-ordination between the public and private sector.

Role of public authorities: public authorities need to shift their role from intervening in prices through altering supply and demand towards creating the necessary institutional framework. The key steps required of the government in this respect are:

a. to pass and implement legislation on warehouse receipt law and the standard conditions for licensed warehouses

b. to set up a licensing and inspection system for the licensed warehouses

c. to set up a performance guarantee system

d. to work with the private sector to establish viable quality standards

Such a shift in roles-from guaranteeing stable price levels to guaranteeing efficient markets is a politically difficult move since food prices are obviously an important and sensitive issue and some farmers are used to have risks covered by the government in 
the form of Market Intervention.

Role of farmers and processors: consultation with farmers and processors is essential to ensure that the planned system suit $s$ their needs and constraints, and to ensure that they understand and support the new legislation. Ongoing feedback once the scheme has started is also important to help fine -tune its operation. As a result, the scheme should be planned through a bottom-up consultative process, not devised as a top - down bureaucratic proposal.

Role of local banks: when the scheme has been set up, the role of the local banks is critical to ensure that it is operable. This requires training bank staff and establishing clear internal procedures, including a system for weekly monitoring of prices of commodities being used as collateral. Warehouses that already have an established relationship with financial institutions are most likely to be seen as credible participants of the scheme at the outset, with acceptability widening to more warehouses once the scheme is shown to operate reliably.

Role of international institutions: these can greatly accelerate the establishment of warehouse receipts systems by supporting the institutional development to assist in providing technical assistance in establishing quality standards, training to warehouse operators and inspectors, advising on draft legislation, help set up performance guarantee schemes and draw on best practices in other countries.

Role of local banks: when the scheme has been set up, the role of the local banks is critical to ensure that it is operable. This requires training bank staff and establishing clear internal procedures including a system for weekly monitoring of prices of commodities being used as collateral. Warehouses that already have an established relationship with financial institutions are most likely to be seen as credible participants of the scheme at the outset, with acceptability widening to more warehouses once the scheme is shown to operate reliably.

\section{Role of international institutions:} these can greatly accelerate the establishment of warehouse receipts systems by supporting the institutional development to assist in providing technical assistance in establishing quality standards, training to warehouse operators and inspectors, advising on draft legislation, help set up performance guarantee schemes and draw on best practices in other countries.

\section{METHODS}

Descriptive research is aimed to explore and clarify regarding to the phenomenon or reality social, by describing some variables concerning problems and examined unit. The type of research used is descriptive qualitative which studies about the available problems and describes 
everything happen right now. In other words, descriptive research analysis aims to obtain the information focusing on reality.

\section{RESULTS AND DISCUSSION}

The potency of warehouse receipt system:

\section{Study of Niaga Mukti Cooperation}

The availability of modal is very necessary to the businessman to guarantee the condition of his business, especially to the farmer and middle-small endeavor in agriculture sector. Farmer or middle-small endeavor often confronts the difficulty in financing and modal problem. It is caused by the limitation of access and credit guarantee in the bank. Some problems push Bappebti to make a decision that is called with warehouse receipt system. The goal is to have a solution to the farmer and middlesmall endeavor to obtain the convenience in financing of agriculture sector.

Farmer who saves rice in the warehouse will obtain a document that is called as warehouse receipt. Warehouse receipt can be used as the guarantee of credit if it fulfills the requirement in the regulation of WRS. Warehouse receipt is published by Warehouse Manager, Niaga Mukti Cooperation that has obtained agreement from supervisor committee. On the other hand, warehouse receipt is only able to be burdened one debt guarantee and the receiver of guarantee must inform a contract of warehouse receipt association as the guarantee to the registration center and warehouse manager. The burden of guarantee toward warehouse receipt is made with agreement certificate guarantee. The guarantee of warehouse receipt is classified in commodity guarantee which means a direct relation toward certain commodity and able to be defended to anyone and able to be transferred by hand to someone else.

The agreement of warehouse receipt warranty is arranged in the regulation of WRS Pasal 14 ayat (1) describes that warehouse receipt is the agreement accessoir, that is additional agreement and related to primary agreement. The primary agreement from it is credit agreement between debtor and bank. In other words, if the credit agreement is canceled, the warranty of agreement is automatically canceled. The warranty of warehouse receipt that is published contains the identity of donator side and receiver the guarantee, data primary agreement guaranteed, warehouse receipt specification used, value of money guaranteed and value of commodity based on the price of market when the commodity is in the warehouse.

The government of Bappebti will give interest income grant to the farmer, farm community, association of farm community and cooperation to obtain credit facility or financing from bank with warehouse receipt grant. The requirement of credit which obtains interest income 
grant with the amount of warehouse receipt is determined in the regulation of Financial Minister No. 17/PMK.05/2009 concerning scheme of Warehouse Receipt Grant. The requirements are:

a. The highest big credit plafond is $70 \%$ from the value of warehouse receipt.

b. The big plafond is determined by Bank or finance institution with Plafond max Rp 75.000.000, 00

c. Maximum plafond is based on total farmer in farmer community, cooperation and the association of farmer community.

d. Maximum plafond is able to be observed every time based on suitability analysis of farm business that is suggested by minister of technique.

If it is farmer in the reality of debtor that is not able to repayment toward credit given by bank, bank has a right to execute toward warehouse receipt warranty. It is arranged in the decision of Pasal 16 ayat (1) the regulation of WRS that the receiver of warranty has a right to sell the object of warranty toward the authority through auction sale or immediate selling.

Based on the result of interview, the execution of warehouse receipt warranty by banking is not conducted yet. Practically, there is no debtor case yet. During this time, credit has been paid before credit is in the due date, so that warehouse receipt warranty is returned to the debtor.

The important thing of the success implementation of WRS in Cianjur is not free from the intensive socialization to the farmer and there is synergy cooperation either regional government or government center and there is a trading minister. On the other hand, warehouse ability (the description of regulation No. 9 2011) is one of the keys of success implementation of WRS. Based on the data from bappebti (2011) has been built the warehouse with fiscal stimulus of trading department (in 34 regions), APBN-P (in 11 regions), and DAK 2011 (15 units).

The support of finance institution becomes a factor of success of the implementation of WRS through either

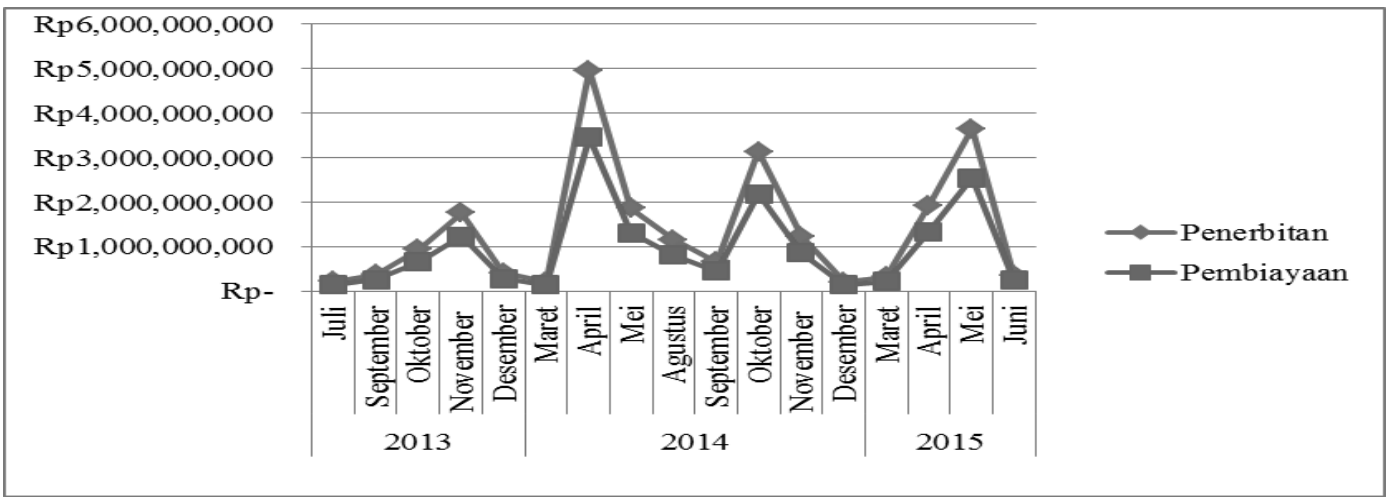

Figure 1. The Development of Warehouse Receipt System Value 
commercial skim or program. It has been supported by Ashari (2011) tells that skim program, finance ministry has issued the regulation of finance minister No. 171/ PMK.05/2009 about the scheme of grant WRS. While, to the implementation of scheme WRS has been published the regulation trading minister No. 66/M-DAG/ $\mathrm{PER} / 12 / 2009$. According to the interview, from 2013 the cooperation of Niaga Mukti cooperated with BJB bank in providing the farm business finance has developed till 2015. It can be seen in graphic below:

This scheme shows that the value of publication of warehouse receipt or financial value is fluctuating. It is caused by the characteristic of rice in different weather so that the price of rice that is determined by cooperation is also fluctuating. The characteristic of rice commodity encourages farmer to save the harvest in warehouse receipt to obtain the income during saving. Generally, the saving period of rice for first-three months and the period of rice saved in warehouse, farmer obtains document warehouse receipt published by Niaga Mukti Cooperation that is able to be guaranteed in BJB to obtain a credit to further operational activity. Thus, farmer will obtain double advantages that are able to obtain modal and get the higher price of rice.

There is an example of the calculation of the advantage of WRS to the farmer in Cianjur in Niaga Mukti Cooperation.
The analysis of GKG is $35.000 \mathrm{~kg}$ for 3 months:

- The price of entire warehouse $\mathrm{Rp} 4.620$ x $35.000 \mathrm{~kg}=\mathrm{Rp} 161.700 .000$

- Interest income for 3 months $(1,5 \%)=$ Rp 2.425.500

- Saving cost, service, bongkar muat, contain $=\operatorname{Rp} 5.250 .000$

- Assurance, registration center, quality test $\mathrm{Rp} 2.425 .500+\mathrm{Rp} 5.250 .000=\mathrm{Rp}$ 7.675 .500

$$
\text { Total : } \underline{\operatorname{Rp} 169.375 .500}
$$

- The price of outcome Rp 5.500 x 35.000 $\mathrm{kg}=\mathrm{Rp} 192.500 .000$

- The income of farmer : Rp 192.500.000

- Rp 169.375.500 = Rp 23.124.500

- Rp 23.124.500 : $35.000 \mathrm{~kg}=\mathrm{Rp} 660 /$ $\mathrm{kg}$

The additional income obtained with the advantage of delay selling is $\mathrm{Rp} 660 / \mathrm{kg}$ for 3 months saving.

Based on the calculation above, it can be seen that by applying warehouse receipt system, farmer will get a higher income margin than they sell to the commission agent. On the other hand, the larger impact by applying WRS to the farmer in Cianjur is increasing the productivity and quality of rice produced and more organized well of management business because farmer is able to determine planting schedule and its marketing. According to Nana Sukatna as the manager of Niaga Mukti Cooperation warehouse, the passion of 
farmer in Cianjur to conduct delay selling system is increased. It can be proven by the use of warehouse receipt for $98 \%$ used as the guarantee of bank to obtain business farm credit.

\section{The challenge of implementation of warehouse receipts system}

The implementation of WRS, Niaga

Mukti Cooperation must confront some challenges that are:

a. To empower economic society through Warehouse Receipt System

The implementation of WRS incidentally is the endeavor to empower economy for the society. It has a rule of sharecropping between cooperation and farmer. By delay selling system farmer or farm community obtains the price of selling rice and cooperation obtains the profit from marketing system or rice distribution either to the big seller or to the exporter.

b. To empower Warehouse Receipt is the alternative finance

Warehouse receipt is able to be guaranteed to obtain credit in BJB. By using the document, farmer can easily to obtain business farm credit without giving any grant of estate, house, vehicle and others. Farmer will obtain low interest income financing that is $6 \%$ per year after getting the grant from government. The payment system and getting a profit for farmer in Cianjur encourages farmer and farm community to save rice in Niaga Mukti Cooperation and makes warehouse receipt as warranty in bank to cost further operational business.

c. To empower warehouse receipt is finance instrument and marketing tool to the farmer and endeavor.

Warehouse can be called as the replacement of cash money after marketing rice. It is different when rice is sold through a commission agent so that they could not get the cash from the product. On the other hand, the profit of warehouse receipt is able to transfer some money to the other farmers so that they can do the transaction in Bank with the warehouse receipt warranty. Warehouse receipt is to ease the trader to obtain the suitable commodity with the best quality based on the trader's criteria.

d. It is necessary to coordinate with strong synergy between government center and region, farmer, farmer community, farmer community association, cooperation, businessman, food resistance agent, warehouse manager and financial institutions/ banking and BUMN.

The success of this program implementation is the good cooperation either government region, center, farmer, community, cooperation or bank. Those institutions have a cooperation and bank and well contribution to encourage the 
increasing income of farmer in Cianjur

that is by applying delay selling system such as PEMDA in Cianjur, trading agent and industry cooperate with Bappebti to do socialization and treatment to the candidate of warehouse manager concerning WRS program. It is also the same with bank under control of Bappebti to cooperate with cooperation as manager of warehouse to publish WRS, to provide, and to increase the obligation of farmer.

e. To provide the cost of operational cultivation and maintenance

The cost of operational that must be available are the cost of construction, transportation or WRS operational need, while the maintenance cost is based on treating and dryer rice tools. Those are well contribution in the implementation of WRS in Cianjur.

f. To provide transportation in WRS It is important to facilitate marketing system. By having the accommodation, it will facilitate warehouse management to distribute commodity from one region to others. However, farmer will get the burden of transportation yet it will not the problem for them to save their rice in warehouse.

g. To build the faith and Honesty

h. Faith and honesty is the main character buried in Niaga Mukti Cooperation to facilitate consumer (trader and farmer) such as the price of rice that must be obtained by farmer before saved for 3 months.

i. Able to operate and maintain rice dryer machine

Dryer machine is one of the profits of Niaga Mukti Cooperation. Therefore, human resource of warehouse manager must able to operate and maintain machine.

\section{CONCLUSION AND SUGGESTION}

1. The potency of WRS implementation is that farmer obtain high rice price and the warehouse receipt is able to be used as the grant of collateral credit in Bank. $\mathrm{BJB}$ as the cost provider cooperated with Niaga Mukti Cooperation gives the easy way to get a credit farm business to the farmer. It is proven that $98 \%$ warehouse receipt is used as the grant in BJB by farmer in Cianjur.

2. Some of the challenges in WRS implementation are centered on economy of the society empowerment; WRS as the alternative cost; warehouse receipt as financial instrument and marketing for farmer or endeavor; the importance of coordination between farmer community, cooperation, government of region/center, banking and BUMN; to provide cultivation operational cost and maintenance and transportation in warehouse; to build the faith and honesty and able to operate and maintain rice dryer machine. 


\section{ACKNOWLEDGEMENT}

Thanks to my partner and my friends in master of agribussiness mangement UGM, my thesis supervisor, Bappebti (Minister of Trade) who has provided information of warehouse receipts system in Cianjur and all those who have complete the research.

\section{REFERENCES}

Anitasari, Rahayu Fery. 2015. The Developments of Warehouse Receipt System And Obstacles Faced. International Journal of Business, Economics And Law, Vol. 6, Issue 4: 105-107.

Apriyantono A. 2004. Pembangunan Pertanian di Indonesia. Visi, Misi, dan Progam 100 Hari Menteri Pertanian. Tersedia pada:http://www. pertanian.go.id/renbangtan/konsep_ pembangunan_pertanian.pdf.

Ashari, 2011. Potensi dan Kendala Sistem Resi Gudang(SRG) untuk Mendukung Pembiayaan Usaha Pertanian di Indonesia. Forum Penelitian Agroekonomi, Vol:29 No.2: 129-143.

Elias, Adalberto. 2016. Recent Electronic Warehouse Receipts Developments In Mexico. Arizona Journal of International \& Comparative Law Vol. 33, No. 1: 199-204.

Hasnain, Syed Samar, Kamran Akram Bakhshi, Ikramullah Qadri, Hasan Murtaza, Mustafa Kamal Mufti. 2014. Framework for Warehouse Receipt Financing in Pakistan. State Bank of Pakistan : Agricultural Credit and Microfinance Department. Pakistan.

Listiani, Nurlia And Bagas Haryotejo. 2013. The Implementation Of Warehouse
Receipt System For Corn: Case Study In Tuban Regency, East Java Province. Buletin Ilmiah Litbang Perdagangan, Vol.7 No.2 : 193-212.

Mahanta D. 2012. Review of Warehouse Receipt as an Instrument for Financing in India. International Journal of Scientific and Technology Research Vol. 1: 42-45.

Nugrayasa O. 2012. 5 Masalah yang Membelit Pembangunan Pertanian di Indonesia. Tersedia pada: http://setkab. go.id/artikel-5746-5-masalah-yangmembelit-pembangunan-pertaniandi-indonesia.html.

Onumah, Gideon. 2010. Implementing Warehouse Receipt System in Africa Potential and challenges. The African Journal of Agricultural and Resource Economics, 1(1) 1-18.

Pargami PA, Alipoor H, Dinpanah G, dan Ansari MH. 2013. Application of Seasional Models in Modeling and Forecasting the Monthly Price of Privileged Sadri Rice in Guilan Province. ARNP Journal of Agricultural and Biological Science. Vol. 8 No. 4: 283-290.

Suryadi, Chandra Fajri Ananda dan Kaptiyah. 2008. Penawaran Padi di Daerah Sentra Produksi dan Kebijakan Produksi di Indonesia. Agritek Vol.16. No.9, September 2008.

Tosun, Savran, et al. 2014. The Evaluation of The Warehouse Receipt System ForAgro-food Product in Turkey. Anadolu J Agr Sci, 2014, 29(3):240247.

Towo, Nathaniel N. 2014. Warehouse Receipt System: A Solution Towards Smallholder Farmers' Financial Constraints?. International Journal of Economics, Commerce And Management. Vol. Ii, Issue 7: 1-20. 